\title{
BAGAIMANA MEMBANGUN KEHIDUPAN SPIRITUAL SELAMA PANDEMI COVID-19 DI MALANG RAYA
}

\author{
Berliany Venny Sipollo ${ }^{1}$, Nadia Oktiffany Putri ${ }^{2}$, dan Kristianto Dwi Nugroho ${ }^{3}$ \\ Program Studi Keperawatan, STIKes Panti Waluya Malang \\ Jl. Yulius Usman No.62, Kasin, Kec. Klojen, Kota Malang, Jawa Timur, 65117, (0341) \\ 369003 \\ e-mail: berlianyvenny@rocketmail.com
}

\begin{abstract}
ABSTRAK
Kegiatan Program Kemitraan Masyarakat dengan judul "Bagaimana membangun kehidupan spiritual selama masa pandemik COVID-19" diawali dengan fenomena yang ada saat ini mengenai COVID-19. Fenomena yang ada menunjukkan jika masyarakat belum siap menerima perubahan yang terjadi akibat kondisi pandemi. Perubahan yang terjadi meliputi kebijakan baru dari pemerintah yaitu PSBB (Pembatasan Sosial Berskala Besar). Kebijakan baru ini diadakan sebagai tindak lanjut dari peningkatan jumlah warga yang terinfeksi dan meninggal akibat COVID-19. Hal ini juga berdampak pada perputaran sektor ekonomi, masyarakat ketakutan berpergian, salah satunya termasuk pergi ke tempat ibadah. Dibutuhkan kesiapan mental bagi masyarakat dalam menghadapi masa pandemic COVID-19. Upaya dalam membangun kehidupan spiritual di masa pandemik COVID-19 dilakukan dengan meningkatkan komunikasi atau silahturahmi, mengurangi paparan berita dari berbagai media, membaca kitab suci, meluangkan waktu untuk beribadah, dan mendengarkan siraman rohani. Salah satu hal positif dalam pandemi ini ialah memperbanyak kesempatan untuk semakin dekat dengan Tuhan yang jika selama ini waktu lebih terkuras habis dengan pekerjaan. Kehidupan spiritual Karakter yang kuat akan meningkatkan spiritual dalam diri masing-masing untuk menghadapi keadaan yang sulit di masa pandemik.
\end{abstract}

\section{Kata Kunci-COVID-19, Edukasi, Membangun kehidupan spiritual, PSBB}

\begin{abstract}
The Community Partnership Program activity entitled "How to build a spiritual life during the COVID19 pandemic period" begins with the current phenomenon regarding COVID-19. The existing phenomenon shows that the community is not ready to accept the changes that occur due to pandemic conditions. Changes that occur include a new policy from the government, namely PSBB (Large-Scale Social Restrictions). This new policy was held as a follow-up to the increase in the number of people infected and dying from COVID-19. This also has an impact on the rotation of the economic sector, people are afraid to travel, one of which includes going to places of worship. It takes mental readiness for the community to face the COVID-19 pandemic. Efforts to build a spiritual life during the COVID-19 pandemic have been carried out by increasing communication or friendship, reducing exposure to news from various media, reading holy books, taking time to worship, and listening to spiritual sermons. One of the positive things in this pandemic is that there are more opportunities to get closer to God, who if all this time has been drained more by work. Spiritual life A strong character will enhance each other's spirituality to face the difficult circumstances of the pandemic.
\end{abstract}

Key Words--- Building a spiritual life, COVID-19, Education, PSBB.

\section{PENDAHULUAN}

COVID-19 adalah penyakit menular yang disebabkan oleh corona virus. Jenis virus ini termasuk virus yang paling baru ditemukan. Virus dan penyakit baru ini tidak diketahui sebelum wabah dimulai di Wuhan, Cina, pada Desember 2019. COVID-19 sekarang menjadi pandemi yang menyerang banyak negara secara global (WHO, 2020). Gejala COVID-19 yang paling umum adalah demam, batuk kering, dan kelelahan. Gejala lain yang kurang umum dan dapat mempengaruhi beberapa pasien termasuk sakit dan nyeri, hidung tersumbat, sakit kepala, konjungtivitis, sakit tenggorokan, diare, kehilangan rasa atau bau atau ruam pada 
kulit atau perubahan warna jari tangan atau kaki. Gejala-gejala ini biasanya ringan dan mulai secara bertahap. Beberapa orang menjadi terinfeksi tetapi hanya memiliki gejala yang sangat ringan (WHO, 2020).

Data penyebaran COVID-19 di Indonesia pada tanggal 26 Mei 2020 didapatkan 22.750 orang yang dinyatakan positif, 1.391 orang yang dinyatakan meninggal, dan 5.642 orang yang dinyatakan sembuh. Pada 29 April 2020 untuk rentang usia 60-79 tahun, sebanyak 311 lansia meninggal dari total yang meninggal 784 orang, sementara untuk usia pasien yang meninggal akibat COVID-19 paling banyak pada rentang usia 30-59 tahun, yakni sebanyak 364 orang di Indonesia (Arifin, 2020). Jawa Timur menjadi peringkat ke dua setelah DKI Jakarta, di Jawa Timur didapatkan data 3.886 orang positif, meninggal 292 orang, dan sembuh 489 orang pada tanggal 26 Mei 2020. Merujuk data Satgas COVID-19 Pemprov Jawa Timur pada tanggal 9 Mei 2020, 71 orang positif COVID-19 merupakan akumulasi jumlah warga terpapar virus Corona di Malang Raya, yang meliputi Kota Malang, Kota Batu, dan Kabupaten Malang. Hal ini terus meningkat jumlah pasien positif COVID-19 telah menembus angka 257 orang pada Minggu, 5 Juli 2020. Pemerintah provinsi Jawa Timur menanggapi kejadian yang ada dengan mengeluarkan beberapa kebijakan dan regulasi terkait COVID-19 (Fajar, 2020).

Salah satu kebijakan baru yang dikeluarkan oleh pemerintah di masa pandemi adalah PMK No.9 Tahun 2020 tentang Pedoman Pembatasan Sosial Berskala Besar Dalam Penanganan COVID-19. Pada PMK tersebut di BAB III tentang Pelaksanaan Pembatasan Sosial Berskala Besar Pasal 13 membahas mengenai pembatasan kegiatan keagamaan. Anjuran dari PMK tersebut ialah masayarakat diminta untuk melaksanakan kegiatan keagamaan di dalam rumah dengan dihadiri keluarga dalam jumlah terbatas dan dengan menjaga jarak antar 1 orang dengan orang lainnya. Kebijakan tersebut juga membuat semua tempat ibadah harus ditutup untuk umum. Selain itu, pemakaman biasa pada jenazah yang tidak terinfeksi COVID-19 boleh dihadiri namun dengan jumlah tidak lebih dari dua puluh orang. Kebijakan tersebut dibuat sebagai upaya untuk memutus rantai penyebaran COVID-19. Kebijakan dan peraturan yang ada, membuat keterbatasan masyarakat dalam melaksanakan kegiatan spiritual atau ibadahnya. Dukungan perawat dibutuhkan dalam menghadapi fenomena COVID-19, terutama kebutuhan spiritual masyarakat.

Peran perawat ialah memberikan perawatan secara holistik dengan memperhatikan aspek biologi, psikologi, sosial, dan spiritual. Upaya dalam membangun kehidupan spiritual di masa pandemik COVID-19 dilakukan dengan meningkatkan komunikasi atau silahturahmi, mengurangi paparan berita dari media apapun, membaca kitab suci, meluangkan waktu untuk semakin dekat dengan Tuhan, dan mendengarkan siraman rohani (Hamid, 2014). Kebutuhan spiritual yang terpenuhi dapat meningkatkan koping untuk menghadapi situasi yang sulit atau menantang. Masa pandemik COVID-19 memerlukan penyesuaian psikologis yang signifikan. Pada kondisi pandemi ini kehidupan spiritual akan menjadi bagian yang sangat penting dari koping. Kehidupan spiritual yang baik akan membangun masyarakat yang kuat secara spiritual dalam menghadapi masa sulit di tengah pandemik COVID-19 (Timmins, 2017).

\section{METODE}

Alat dan bahan terdiri dari video Edukasi "5 Cara Membangun Kehidupan Spiritual Selama Pandemi COVID-19", media social dan zoom (sebagai sarana 
komunikasi), google form (pre test dan post test). Metode pelaksanaan membagikan video 5 Cara Membangun Hubungan Spiritual Dalam Masa Pandemi COVID-19 ke Youtube dan grup media sosial. Selain itu, juga melakukan pertemuan melalui aplikasi zoom edukasi pada beberapa grup.

\section{HASIL dan PEMBAHASAN}

Tabel 1 Tabel Kegiatan dan Hasil

Kegiatan Pengabdian Masyarakat pada bulan Agustus 2020.

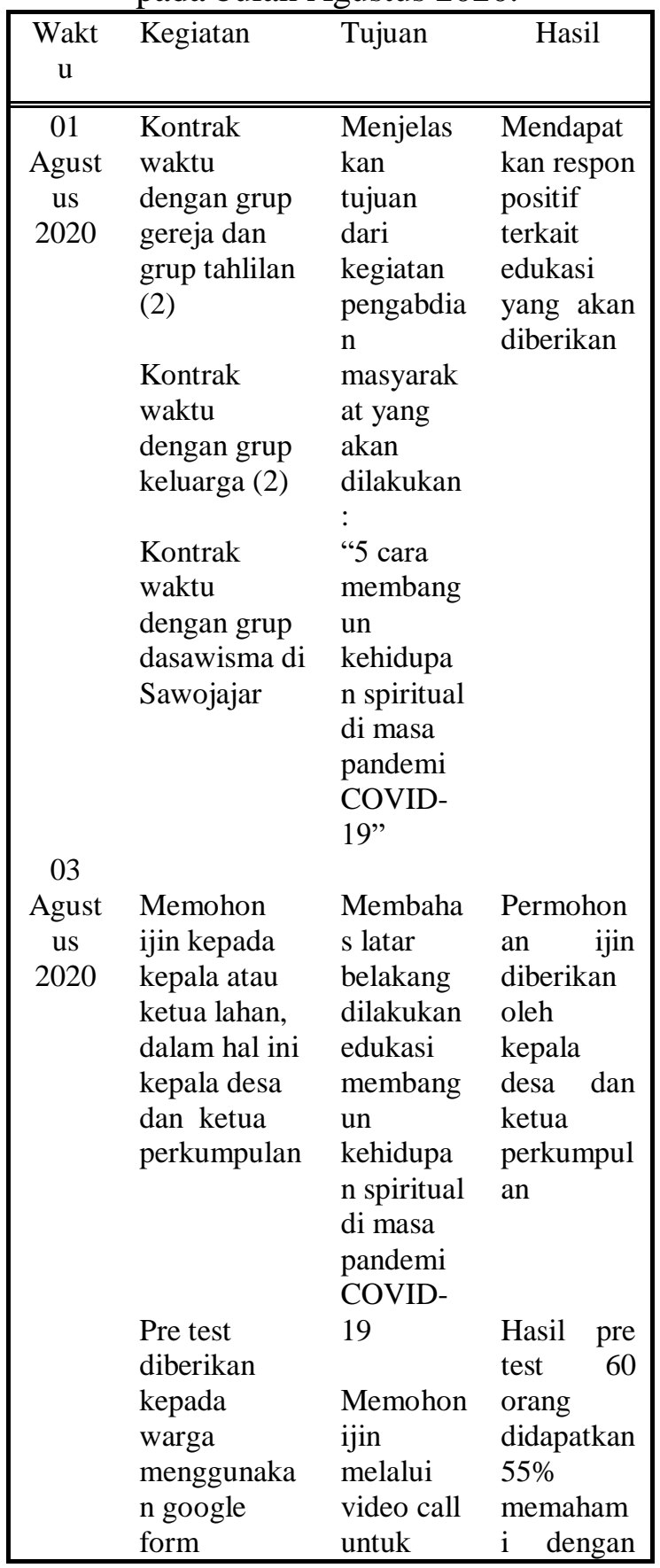

\begin{tabular}{|c|c|c|c|}
\hline \multirow[t]{2}{*}{$\begin{array}{c}17 \\
\text { Agust } \\
\text { us } \\
2020\end{array}$} & $\begin{array}{l}\text { "Edukasi } 5 \\
\text { Cara } \\
\text { Membangun } \\
\text { Kehidupan } \\
\text { Spiritual", } \\
\text { sebagai } \\
\text { berikut: } \\
\text { 1. } \\
\text { Meningkat } \\
\text { kan } \\
\text { komunikasi } \\
\text { atau } \\
\text { silahturah } \\
\text { mi } \\
2 . \\
\text { Mengurang } \\
\text { i paparan } \\
\text { media } \\
\text { berita dan } \\
\text { media } \\
\text { social } \\
3 . \\
\text { Membaca } \\
\text { kitab suci } \\
4 . \\
\text { Meluangka } \\
\text { n waktu } \\
\text { untuk } \\
\text { beribadah } \\
5 . \\
\text { Mendengar } \\
\text { kan } \\
\text { siraman } \\
\text { rohani }\end{array}$ & $\begin{array}{l}\text { dilakukan } \\
\text { edukasi } \\
\text { Pre test } \\
\text { mengetah } \\
\text { ui } \\
\text { pemaham } \\
\text { an warga } \\
\text { dalam } \\
\text { membang } \\
\text { un } \\
\text { kehidupa } \\
\text { n } \\
\text { spirirtual } \\
\text { sebelum } \\
\text { edukasi } \\
\text { Memberi } \\
\text { kan } \\
\text { informasi } \\
5 \text { Cara } \\
\text { Membang } \\
\text { un } \\
\text { Kehidupa } \\
\text { n } \\
\text { Spiritual } \\
\text { di masa } \\
\text { pandemi } \\
\text { COVID- } \\
19\end{array}$ & $\begin{array}{l}\text { Para } \\
\text { warga } \\
\text { mengerti } \\
\text { tentang } 5 \\
\text { Cara } \\
\text { Membang } \\
\text { un } \\
\text { Kehidupa } \\
\text { n Spiritual } \\
\text { di masa } \\
\text { pandemi } \\
\text { COVID- } \\
19 \\
\text { Dari } 60 \\
\text { orang } \\
\text { didapatkan } \\
\text { peningkata } \\
\text { n } \\
\text { pengetahu } \\
\text { an } \\
\text { menjadi } \\
80 \% \\
\text { memaham } \\
\text { i dengan } \\
\text { baik cara } \\
\text { membang } \\
\text { un } \\
\text { kehidupan } \\
\text { spiritual di } \\
\text { masa } \\
\text { pandemi } \\
\text { COVID- } \\
19\end{array}$ \\
\hline & $\begin{array}{l}\text { Post test } \\
\text { dilakukan } \\
\text { pada warga }\end{array}$ & & \\
\hline
\end{tabular}


Secara umum acara berjalan dengan lancar sesuai dengan yang diharapkan. Keberhasilan suatu kegiatan sangat tergantung pada peran aktif dan partisipasi pesertanya. Peran aktif peserta dalam kegiatan "Bagaimana membangun kehidupan spiritual selama pandemi COVID-19 di Malang Raya" ini dapat disimpulkan baik. Hal ini dapat dilihat dari antusias dan semangat dari peserta. Indikasi lain yang menguatkan kesimpulan ini adalah terjadi peningkatan pemahaman membangun kehidupan spirirtual di masa pandemi COVID-19 sejumlah $80 \%$.

Kegiatan edukasi ini dapat berjalan dengan lancar dikarenakan adanya faktor yang mendukung, diantaranya antusiasme para peserta pelatihan yaitu antusiasme peserta yang dapat dibuktikan dengan banyaknya pertanyaan yang muncul ketika pelaksanaan edukasi dan diskusi oleh masyarakat yang sebagaian besar berusia dewasa muda sampai lansia. Faktor lain yang mendukung terlaksananya kegiatan edukasi ini adalah dukungan dari kepala desa, tokoh masyarakat, peran aktif ketua perkumpulan beserta Tim Pengabdi dari STIKes Panti Waluya Malang dan juga mahasiswa yang terlibat langsung pada kegiatan ini. Pada kegiatan ini tidak ditemukan faktor penghambat yang berarti, sehingga kegiatan dapat berjalan dengan lancar.

\section{KESIMPULAN DAN SARAN}

Pelaksanaan Program Pengabdian kepada Masyarakat ini dapat disimpulkan telah berjalan dengan baik, lancar, dan sukses. Hal ini dikarenakan pada saat pelaksanaan kegiatan "Bagaimana membangun kehidupan spiritual selama pandemi COVID-19 di Malang Raya" yang telah dilaksanakan selama 2 hari, tingkat kehadiran peserta selalu $100 \%$, tersampaikannya semua materi oleh narasumber dan aktifnya peserta dalam diskusi yang dilakukan.
Hal lain yang dapat dijadikan barometer kesuksesan acara ini adalah dari hasil evaluasi pada peserta saat dilaksanakan edukasi. Peserta terlihat lebih antusias dalam memahami bagaimana membangun kehidupan spiritual selama pandemi COVID-19. Atas dasar ini pula dapat disimpulkan bahwa tujuan edukasi yang ingin meningkatkan pengetahuan dan pemahaman warga Malang Raya mengenai membangun kehidupan spiritual dapat tercapai.

\section{UCAPAN TERIMA KASIH}

Pelaksana mengucapkan terima kasih kepada STIKes Panti Waluya Malang yang mendukung kegiatan Pengabdian kepada Masyarakat dengan memberikan dana hibah dan fasilitas. Terimakasih kepada tim Pengabdian Kepada Masyarakat (Nadia Oktiffany dan Kristianto Dwi Nugroho) yang telah mendukung dengan sepenuh hati.

\section{DAFTAR PUSTAKA}

Arifin, Zainul. "Update Corona Covid19 Di Malang Raya, 21 Kasus Positif Dan 8 Meninggal Dunia." liputan6.Com, Liputan6, 22 July 2020,www.liputan6.com/regional/re ad/4225251/update-corona-covid19-di-malang-raya-21-kasus-positifdan-8-meninggal-dunia.

Fajar, Ihwan. "Skeptisisme Warga Ancaman PSBB Malang Raya." TAGAR, Tagar.id, 23 Dec. 2017, www.tagar.id/skeptisisme-wargaancaman-psbb-malang-raya.

Hamid, A. Yani. (2014). Buku Ajar Spiritual Dalam Keperawatan, Jakarta: Widya Medika

$\begin{array}{rrr}\text { PMK No.9 } & \text { Tahun } 2020 & \text { Tentang } \\ \text { Pedoman } & \text { Pembatasan } & \text { Sosial }\end{array}$


Berskala Besar Dalam Penanganan COVID-19

Timmins F, et al (2017) Understanding spirituality and spiritual care in nursing. Nursing Standard. 31, 22, $50-57$

World Health Organization, 2020, COVID-19. 